\title{
Eroticon DVD
}

\author{
By Jan Uhde
}

Fall 2007 Issue of KINEMA

THE FILM WORLD is familiar with Gustav Machatý's Ecstasy (Extase, 1932) with Hedy Lamarr (b. Kiesler) that became famous as the first mainstream movie featuring full frontal female nudity. This probably contributed to the fact that the director's earlier silent feature Erotikon (1929) is much less known, despite being called "the most important Czech film of the silent era."

Machatý's Erotikon (not to be confused with the eponymous Swedish feature made in 1920 by Mauritz Stiller) is a story of passion, starring the Slovenian-born actress Ita Rina. Like Ecstasy, it created controversy, especially because of the frankness with which Machatý portrayed love scenes. Formally, Erotikon is indebted to the German Kammerspielfilm, or "intimate cinema," an influential 1920s style, related to film expressionism. The Czech National Film Archive DVD set contains the well-restored feature as well as several bonuses, including selections from the film archive of the director.

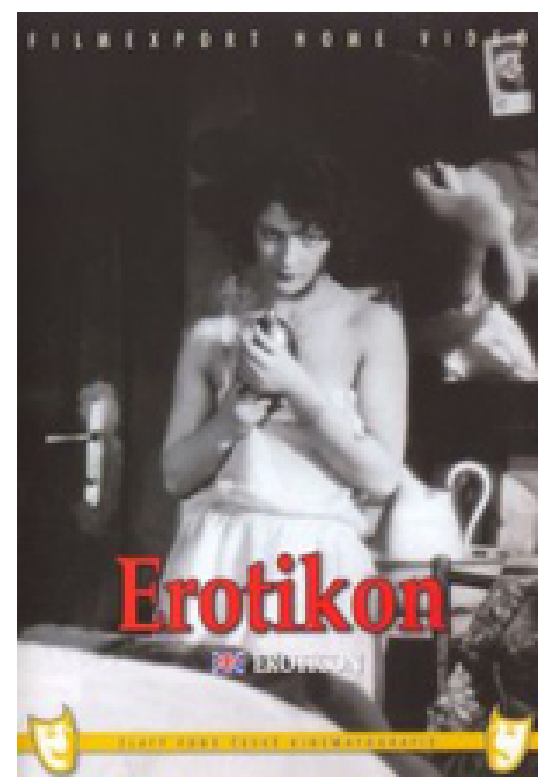

Figure 1: EROTICON DVD (Erotikon, Gustav Machatý, đ Czechoslovakia 1929, 2-disc set), PAL, All regions, ๆ DVD-9, 85min, b\&w. I Filmexport Home Video (Czech Republic). I Silent. Czech and English intertitles. ฯ CZK 299.00 (USD 17.00) Sold online.

\section{Author Information}

Jan UHDE is Professor Emer. (Film Studies) at the University of Waterloo, Ontario, Canada. Born in Brno, Czech Republic. Graduated (MA) from the Faculty of Arts, Masaryk University, Brno; PhD received at the University of Waterloo, Ontario, Canada. He taught at the University of Waterloo (1970-2012) where he founded a General and Honours BA program in Film Studies at the Department of Fine Arts.

Publications: Latent Images: Film in Singapore Second edition, with Yvonne Ng Uhde (Ridge Books, National University Press of Singapore, 2010); Latent Images: Film in Singapore, with Yvonne Ng Uhde (Oxford University Press, 2000); Latent Images: Film in Singapore CD-ROM (2003, co-author); Vision and Persistence: Twenty Years of the Ontario Film Institute (University of Waterloo Press, 1990) and Ontario Film Institute Programming Activities Index 1969-1989 (Toronto: Ontario Science Centre, 1990). He co-edited the Place in Space: Human Culture in Landscape (Proceedings from the Second International Conference of 
the Working Group "Culture and Landscape" of the International Association of Landscape Ecology, Pudoc Scientific Publishers, Wageningen, Holland, 1993). Jan Uhde has published articles and reviews in several countries (including Canada, USA, Germany, Italy), participated in international juries at film festivals and presented papers at international conferences in North America and Europe. In 1998/99, he was a visiting researcher at the School for Film and Media Studies, Ngee Ann Polytechnic, Singapore.

His professional and research interests focus on Singapore cinema; the identification and distancing mechanisms of the film viewer; the non-authored modifications and manipulation of films; and specific aspects of film history, including the Central European cinema.

He founded KINEMA in 1993. 